\title{
Drug Use and High-risk Sexual Behavior among School-Going Adolescents in Nigeria
}

\author{
Emmanuel O. Amoo ${ }^{1}$, Olujide A. Adekeye ${ }^{2 \star}$, Florence Omumu ${ }^{3}$, Olubunmi O. Akinpelu ${ }^{1}$, Mofoluwake P. Ajayi ${ }^{4}$, Tomike Olawande ${ }^{4}$, \\ Susan O. Adeusi ${ }^{2}$ \\ ${ }^{1}$ Demography and Social Statistics, Covenant University, Ota, Nigeria; ${ }^{2}$ Department of Psychology, Covenant University, Ota, \\ Nigeria; ${ }^{3}$ Department of Counselling Psychology, Delta State University, Abraka, Nigeria; ${ }^{4}$ Department of Sociology, Covenant \\ University, Ota, Nigeria
}

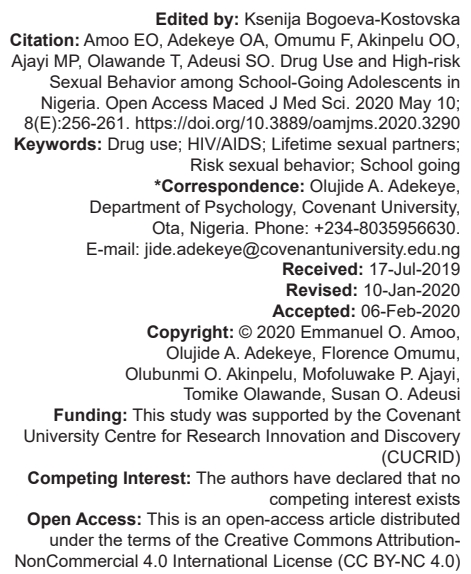

Introduction

In spite of the national agenda of ending the incidence of HIV and AIDS in Nigeria by 2030 through the 90-90-90 strategy, test and treat framework, and pursuit of Sustainable Development Goals-3 [1], [2], the incidence of multiple indicators of sexual risk behavior orchestrated by drug use could be major threats to the achievement of these goals. High-risk sexual behavior and drug abuse among the young people remained perpetual topical issues of focus in most developmental programs, especially as it relates to developing countries [3], [4], including Nigeria [5], [6], [7]. The level of adolescent pregnancy, sexual violence such as abuses, and other harmful trajectories including STIs and HIV has no record of tangible declining in Nigeria [8], [9], [10], [11]. While drug use has been reported to have negative consequences on academic performance and well-being [12], it is a prominent driver of high-risk sexual behaviors among the adolescents [13], [14], [15]. Notwithstanding, exclusive examination among school-going adolescents that are more vulnerable is not popular in the literature, especially in Nigeria, where $60 \%$ of the children are school going and huge potential of increasing net enrolment ratio (male, $72 \%$ and female, 68\%) [16], [17].

There are no consensuses on the actual prevalence rate of the use of drug among adolescents, different countries, and different institutions have their own peculiarities in this regard. In countries where drug use is permitted, certain higher level of use might be expected compared to countries it is outlawed, though empirical information are rare to substantiate this fact. The lifetime marijuana use prevalence in Zimbabwe ranges between $3 \%$ and $12 \%$ [18]. It was also reported that among the adolescent, illicit drug use is positively associated with their experiences of sexual intercourse (Rudatsikira et al., 2009) [18]. In Nigeria, while drug/substance use is not new [19], [20], just like other sub-Saharan African countries, the high level of ingenuity is giving birth to numerous complex mixtures, 
experimentations, and new discoveries of materials and volatile solvents (or inhalants) that are being drank or inhaled with immediate intoxicating effect or other diverse consequences [20], [21], [22]. Although there are some restrictions in terms of access to these drugs in Nigeria, the advancement in technologies and the struggle for means of livelihood could enhance their mass production, availability, and affordability.

Conceptually, drug use and substance use are used interchangeably in the literature. However, drugs in the medical sense could connote medicine mostly prescribed by doctors for therapeutic purposes, especially toward the cure, treatment, prevention, and diagnosis of diseases, to engender relief, enhance mental or other physical well-being [20], [23]. Drugs could also be food supplements such as vitamins and other materials necessary for bodily well-being [23]. Its abuse is most commonly referred to as substance abuse. Specially, substance, in addition to drug, includes chemicals, nicotine, caffeine, alcohol, opiates, amphetamines, cocaine, gasoline, heroine, and glue (Obiechina and Isiguzo, 2016) [23], to mention but few. These are used to induce physiological or psychological effects other than therapeutic intention, especially for pleasure (Obiechina and Isiguzo, 2016) [23]. Drug abuse or substance use is, therefore, considered as the intentional use of chemical substances for reasons different from the intended medical purposes. As noted by Carroll (1989) [24] and Essien (2010) [25], drug use is the use substance(s) to change either the function or structure of the organism but drug is abused when it is taken more than as prescribed.

This distinction gives rise to two basic categories of drugs of which one represents the scope of this study: (1) The legally approved and acceptable drugs, that are, in most cases, normally prescribed by medical personnel and (2) the illegal or community disapproved drugs. One of the major characteristics of the later use of substance is that it is always done in secrecy. This may be due to the stand of the laws against or due to inherent risk behavior associated with its manifestation. However, the consequences of its use are always openly revealed and perhaps when someone suffering from the consequences visits the hospital for treatment or when the users are intercepted by the law enforcement agents. The various reports from the NDLEA revealed a continuous increase in drug abuse from 1977 to 1996 [25]. The marijuana with various generic names such as weeds, pep, Indian hemp, Igbo, Ganja, and superman pill is regarded as most common among young students [22], [25], [26].

Ordinarily, the transition to adulthood from adolescence is not a benign process. The myriads of challenges adolescents are exposed to are multifaceted. It is a period of acquiring competencies, attitudes, and values that set the stage for continued development and the foundation for informed choices in life including dramatic changes in the body [8], [9], [21], [27], [28]. Adolescents are faced with the first experience of some life events such as intimate partnership, first sexual experience, and sexual identity [27], [28]. As schoolgoing adolescents, there is high expectation that they should be preoccupied with educational growth, goals for good academic performance/outcomes, and future plans. However, studies have established that low academic performance or disinterests in academics are associated with person's environment and behavior including mental health [28]. The use of drugs or substances that could alter normal behavior or mental stability may be detrimental to adolescent not only in terms of academic but also overall well-being. The use of substances has been noted for altering of body functioning and mind with great consequences on their health [20], [23]. Besides, the limited time to be spent for academic learning could be dissipated on investigating disciplinary issues. The user also may be victim and perpetrator of violence, rape, suicide, or robbery, and cultism among other anti-social vices. It is also a prominent driver of youth's incarceration [25]. The penalty for offender ranges from counseling, suspension, and final rustication and to litigations between the offender and the state law enforcement agency. This points to the fact that drug use among teenagers transcend beyond the person involved but also his/her immediate and distant community and its citizenry.

There have been several attempts to curb the menace of risky sexual behavior and substance use. The Convention on the Rights of Child concerns with the protection of youth well-being and adolescents; the ICPD program of action with adequate provisions to guide adolescents and youth against high-risk childbearing and high-risk sexual behavior among adolescents and youths [8], [21], [29], [30], [31]. Nigeria, like other countries, has developed a national health policy directed toward prevention of risky sexual behavior among the youth and adolescent [32]. Despite all these, there is a lack of consensuses on adequate check on the prevalence, in addition to the paucity of literature addressing the comparisons in sexual behavior between users and non-users of drugs among school-going adolescents. Thus, this study focuses on underscoring the variation in risky sexual behavior among school-going users and non-users of drugs. It also analyzed the predisposing factors of drug use among school-going adolescents in Nigeria.

\section{Materials and Methods}

\section{Research design}

The problem behavior theory was adopted and the 2012 National HIV and AIDS and Reproductive Health Survey (NARHS Plus II) dataset. The data were collated by the Nigerian Federal Ministry of Health with support from Enhancing Nigeria's Response to HIV, Department 
for International Development, and the United States Agency for International Development. The Society for Family Health provided the technical support [33]. The survey is a bi-annual national survey from 2003 and covers all the local government in Nigeria. The extracted sample data for this study are $11,799(n=29,438)$ [33].

\section{Data measurement}

Only data pertaining to school-going respondents were extracted for both male and female. Conceptually, adolescent high-risk sexual behavior is described as those behavior of adolescent make them susceptible to contracting sexually transmitted infections (STIs), unplanned pregnancy or influencing them to be in sexual relationship before having matured knowledge of healthy relationship [34]. Such behavior includes but not limited to having multiple sexual partners, having sex under the influence of alcohol or drugs and unprotected sex [21], [34], [35]. However, variables analyzed were those related to drug use, life style/behavior, and demographic profiles. These include indices of sexual behavior, marital status, living arrangement, age at first sex, number of spouses/sexual partners, frequency of sex, use of condoms, and ever paid for sex, currently using any drug and HIV status among others. The choice of these variables was guided by the description and classification of sexual behavior indicators in the Integrated Demographic Health Survey Data Descriptions by measures DHS and as contained in studies related to substance use [8], [20], [21], [22], [33], [36]. The variables used include age at first sex, being sexually active, sex with non-marital partner, commercial sex, and few indices of substance use: Use of drug, alcohol, smoking, and injection of drug. The DHS did not go through the psychometric rudiments as prescribed by Odukoya et al. (2018) [37] because they are valid, reliable and has been widely applied.

\section{Data analysis}

The study employed only univariate and multivariate levels of analysis. The univariate segment features descriptive statistics which are presented in frequency tables with means and median statistics used where necessary (Table 1). These were specifically used to profile the background information about the respondents, show the trends in adolescent's sexual behavior and the use of drug. The multivariate analysis used binary logistic to illustrate the influence of selected background variables over risky sexual behavior. The indicators of risky sexual behavior used are sex with non-spouse, non-use of condom, and multiple sexual partners. These variables were computed as binary response variables to fit appropriately into the test technique (binary logistic).
Table 1: Sociodemographic profile of youth in Nigeria

\begin{tabular}{|c|c|c|}
\hline Variables & Frequency & $\%$ \\
\hline \multicolumn{3}{|l|}{ Age group } \\
\hline $15-19$ & 5243 & 52.0 \\
\hline $20-24$ & 4848 & 48.0 \\
\hline Total & 10,091 & 100.0 \\
\hline \multicolumn{3}{|l|}{ Gender } \\
\hline Male & 4508 & 44.7 \\
\hline Female & 5583 & 55.3 \\
\hline Total & 10,091 & 100.0 \\
\hline \multicolumn{3}{|l|}{ Residence } \\
\hline Urban & 3050 & 30.2 \\
\hline Rural & 7041 & 69.8 \\
\hline Total & 10,091 & 100.0 \\
\hline \multicolumn{3}{|l|}{ Marital status } \\
\hline Never married & 7076 & 71.2 \\
\hline Married/LWSP & 2759 & 27.8 \\
\hline Separated/divorced & 98 & 1.0 \\
\hline Total & 9933 & 100.0 \\
\hline \multicolumn{3}{|l|}{ Education } \\
\hline Primary school & 595 & 7.9 \\
\hline Secondary school & 1074 & 14.2 \\
\hline Tertiary & 5877 & 77.9 \\
\hline Total & 7546 & 100.0 \\
\hline \multicolumn{3}{|l|}{ Religion affiliations } \\
\hline Islam & 4128 & 40.9 \\
\hline Christianity & 5849 & 58.0 \\
\hline Other religion & 114 & 1.1 \\
\hline Total & 10,091 & 100.0 \\
\hline \multicolumn{3}{|c|}{ Involvement in religious activities } \\
\hline Everyday & 3965 & 39.4 \\
\hline More than once a week & 5504 & 54.6 \\
\hline Less often & 290 & 2.9 \\
\hline Not at all & 315 & 3.1 \\
\hline Total & 10,074 & 100.0 \\
\hline
\end{tabular}

\section{Results}

The demographic profile of the youth covered by the survey indicated a gender ratio of 44.7:55.3 male and female, respectively. Although the dataset covered all population in age 15-49 (females) and 15-65 (males), only information related to the youth (age 15-24 years) was extracted for this study. The age information revealed that $52 \%$ were below 20 years while $48 \%$ belong to the older youth age (20-24 years). Urban residents' proportion was $30.2 \%$ while the rural sample covered was $69.3 \%$. More than two-third of the youth have not married as at the time of the survey while $27.8 \%$ were married or currently living with partner. In terms of education, the educational status was used to measure the proportion of school-going youth in various levels of education categories as at the time of the survey. The proportion in lower level of education cadre (primary school) was $7.9 \%$, secondary school was $14.2 \%$ while $77.9 \%$ were in tertiary institution as at the time of the survey. The proportion of youth practicing Islam and Christianity was $40.9 \%$ and $58.0 \%$, respectively. However, among these groups, $39.4 \%$ were involved in religious activities everyday, $54.6 \%$ engages in religious activities more than once in a week, $2.9 \%$ do so less often, while $3.1 \%$ were not engaged in religious activities at all.

Bivariate analysis reflected the distribution of selected sociodemographic profile of youth in Nigeria. As earlier indicated, variables selected are those that have been used by other studies or classified as sexual behavior indicator by the Integrated Demographic Health Survey Data Descriptions by measures DHS or 
drug factors (Table 2). The variables used include age at first sex, being sexually active, sex with non-marital partner, commercial sex, and few indices of substance use: Use of drug, alcohol, smoking, and injection of drug.

Table 2: Sexual behavior among the youth by gender

\begin{tabular}{|c|c|c|c|}
\hline Variables & $\begin{array}{l}\text { Male } \\
(n=1712)(\%)\end{array}$ & $\begin{array}{l}\text { Female } \\
(\mathrm{n}=3366)(\%)\end{array}$ & $\begin{array}{l}\text { Total } \\
(\mathrm{n}=5078)(\%)\end{array}$ \\
\hline \multicolumn{4}{|l|}{ Age at first sex } \\
\hline None & $3(0.8)$ & $15(0.7)$ & $18(0.7)$ \\
\hline Less than 10 & $4(1.1)$ & $4(0.2)$ & $8(0.3)$ \\
\hline $10-14$ years & $14(3.9)$ & $441(20.6)$ & $455(18.2)$ \\
\hline $15-19$ & $176(48.6)$ & $1280(59.7)$ & $1456(58.1)$ \\
\hline $20-24$ & $165(45.6)$ & $403(18.8)$ & $568(22.7)$ \\
\hline Total & $362(100)$ & $2143(100)$ & $2505(100)$ \\
\hline \multicolumn{4}{|c|}{ Sexual active in the past 12 months } \\
\hline Yes & $1444(84.0)$ & $2900(86.3)$ & $4344(85.5)$ \\
\hline No & $275(16.0)$ & 461 (13.7) & $736(14.5)$ \\
\hline \multicolumn{4}{|c|}{ Non-marital/non-cohabiting sex } \\
\hline None & $423(30.0)$ & $2040(72.8)$ & $2463(58.5)$ \\
\hline Only one & $657(46.7)$ & $657(23.5)$ & $1314(31.2)$ \\
\hline Two or more & $328(23.3)$ & $104(3.7)$ & $432(10.3)$ \\
\hline Total & $1408(100)$ & $2801(100)$ & $4209(100)$ \\
\hline \multicolumn{4}{|l|}{ Alcohol drinking } \\
\hline Never & 3585 (79.9) & $5059(91.0)$ & $8644(86.1)$ \\
\hline Everyday & $146(3.3)$ & $72(1.3)$ & $218(2.2)$ \\
\hline Not often & $754(16.8)$ & $427(7.7)$ & $1181(11.8)$ \\
\hline \multicolumn{4}{|c|}{ Currently smoking } \\
\hline Yes & $74(1.6)$ & $16(0.3)$ & $90(0.9)$ \\
\hline No & $4425(98.4)$ & $5554(99.7)$ & 9979 (99.1) \\
\hline Total & $4499(100)$ & $5570(100)$ & $10,069(100)$ \\
\hline \multicolumn{4}{|c|}{ Ever injected cocaine } \\
\hline Yes & $11(0.2)$ & $64(1.2)$ & $75(0.8)$ \\
\hline No & 4459 (99.8) & $5465(98.8)$ & $9924(99.2)$ \\
\hline Total & $4470(100)$ & $5529(100)$ & 9999 (100) \\
\hline \multicolumn{4}{|l|}{ Ever used drug } \\
\hline Yes & $44(41.2)$ & $65(23.8)$ & $109(22.7)$ \\
\hline No & $164(78.8)$ & $208(76.2)$ & 372 (77.3) \\
\hline Total & $208(100)$ & $273(100)$ & 481 (100) \\
\hline \multicolumn{4}{|l|}{ Commercial sex } \\
\hline Yes & $147(8.6)$ & $279(8.3)$ & $426(8.4)$ \\
\hline No & 1565 (91.4) & 3087 (91.7) & 4652 (91.6) \\
\hline Total & $1712(100)$ & $3366(100)$ & $5078(100$ \\
\hline
\end{tabular}

The proportion of girls who had sex at age $\leq 14$ was $20.6 \%$ far higher than boy's proportion of $3.9 \%$. The result revealed that more than half of the youth (male and female) had sexual experience by age 15-19 (female, 59.7\% and male, 48.6\%). The result of the analysis also revealed that over $80 \%$ of the youth are sexually active (within the past 12 months of the survey). The non-marital sex revealed that $70.0 \%$ and $27.2 \%$ of male and female youth, respectively, have had sex with at least one non-marital and noncohabiting partner. In addition, 8.6\% (male) and 8.3\% (female) have exchanged sex for materials, money, or directly involved in commercial sex. Question on the lifetime sexual partners revealed that $27.3 \%$ (male) and $31.8 \%$ (female) have had $\geq 2$ sexual partners in their life. The result revealed that $32.5 \%$ (male) and 33.4 (female) use drug. Specifically, the proportion that takes alcohol was $14.0 \%$ (male $=20.1 \%$, female $=9.0 \%$ ). Less than $1.0 \%$ of the sampled youth were currently smoking and relatively the same proportion have ever injected cocaine. Apart from the specific substances that were identified among the subjects, quite a number of the respondents indicated that they have tried other types of drugs.

At the multivariate level (Table 3), religion, gender (female), alcohol, and smoking are statistically significant to engagement in non-marital, non-cohabiting partners. Youth practicing Christianity and other religions
Table 3: Binary logistic illustrating the responsiveness of risk sex behavior to selected demographic and sexual behavior

\begin{tabular}{|c|c|c|c|}
\hline Variables & B & Sig. & $\operatorname{Exp}(B)$ \\
\hline \multicolumn{4}{|l|}{ Religion affiliations } \\
\hline Islam & $\mathrm{RC}$ & & \\
\hline Christianity & 0.943 & 0.003 & 2.568 \\
\hline Other religion & 1.188 & 0.038 & 3.282 \\
\hline \multicolumn{4}{|l|}{ Education status } \\
\hline Primary school & $\mathrm{RC}$ & & \\
\hline Secondary school & 0.356 & 0.407 & 1.427 \\
\hline Tertiary & 0.467 & 0.270 & 1.596 \\
\hline \multicolumn{4}{|l|}{ Age group } \\
\hline $15-19$ & $\mathrm{RC}$ & & \\
\hline $20-24$ & -0.061 & 0.880 & 0.941 \\
\hline $25+$ & 0.332 & 0.391 & 1.394 \\
\hline \multicolumn{4}{|l|}{ Residence } \\
\hline Urban & $\mathrm{RC}$ & & \\
\hline Rural & 0.066 & 0.774 & 1.069 \\
\hline \multicolumn{4}{|l|}{ Gender } \\
\hline Male & $\mathrm{RC}$ & & \\
\hline Female & -1.505 & 0.000 & 0.222 \\
\hline \multicolumn{4}{|l|}{ Age at first sex } \\
\hline None & $\mathrm{RC}$ & 0.533 & \\
\hline Less than 10 & 0.608 & 0.669 & 1.838 \\
\hline $10-14$ & 1.053 & 0.022 & 2.866 \\
\hline $15-19$ & -0.320 & 0.700 & 0.726 \\
\hline $20-24$ & -0.574 & 0.489 & 0.563 \\
\hline \multicolumn{4}{|l|}{ Religious activities } \\
\hline Everyday & $\mathrm{RC}$ & & \\
\hline More than once/week & 0.236 & 0.370 & 1.266 \\
\hline Less often & -0.154 & 0.818 & 0.857 \\
\hline Not at all & 0.684 & 0.239 & 1.982 \\
\hline \multicolumn{4}{|l|}{ Alcohol drinking } \\
\hline Never & $\mathrm{RC}$ & & \\
\hline Everyday & 0.724 & 0.043 & 2.063 \\
\hline Not often & 0.777 & 0.000 & 2.174 \\
\hline \multicolumn{4}{|l|}{ Currently smoking } \\
\hline Yes & $\mathrm{RC}$ & & \\
\hline No & -1.053 & 0.022 & 0.349 \\
\hline \multicolumn{4}{|l|}{ Ever injected cocaine } \\
\hline Yes & $\mathrm{RC}$ & & \\
\hline No & -0.341 & 0.579 & 0.711 \\
\hline Constant & -1.943 & 0.112 & 0.143 \\
\hline
\end{tabular}

are, respectively, 2.568 and 3.282 times more likely to be engaged in non-marital/non-cohabiting sex compared to their counterparts in Islamic region. It is statistically significant at $p<0.05$. The female is 0.222 times less likely to engage in non-marital sex compared to their male counterpart. The result also indicated that the higher the age, the less the likelihood of engaging in risky sexual behavior. Younger age group (14 years and below) is positively related to risky sexual behavior compared to older ages (20 years and above). Alcohol intake at whatever level or stage is positively related to risky sexual behavior ( $p<5 \%$ ). Respondents who have not injected cocaine are 0.711 less likely to be involved in risk sexual behavior. Similar result was obtained in analyzing for interlink between smoking and risk sexual behavior among the youth (odds ratio $=0.349, p=0.022$ ).

\section{Discussion}

The study provided empirical information on the variation in male/female youth sexual behavior in Nigeria and shed light on the drivers of risk sexual behavior among the young population. The study revealed the interrelationships between substance use among the school-going adolescents (male and female) and risky sexual behavior using a national 
representative indigenous dataset from the ministry responsible for health and youth in general. The findings from this study extend beyond existing studies on adolescents and substance use [18], secondary school students and drug use [23], challenges in adolescent transition [28], or drug use among tertiary institutions students [24], [25]. The study added to the body of knowledge on the areas of religion and religious activities and sexual behavior, the finding which could be relevant in a country (like Nigeria) where religion and culture are inseparable. In addition, the findings could be a national potential guide on decisions or policies related to sexual and reproductive health strategies and plans for Nigeria and by extension, sub-Saharan Africa.

The lower age at exposure to sex, marriage, or drug use could be inimical to the children health, education, and total well-being or academic performance [38], [39]. In this regard, if the high proportion of youths who are at the onset of prime age of life is considered, a more encompassing program could be exigent to harness the potential of this youth toward economic development of their country and the world at large. The fact that the study revealed that as the youth progress in their education level, the more likelihood of engaging in risky sexual behavior, could be important to the analysis of challenges against initiatives in the areas of sexual behaviors and spread of STIs, HIV, and AIDS in Nigeria. However, this is at variance with numerous studies, where educational attainment has been adjudged as important factor or tool to be used in checking increase in STIs, HIV, or AIDS. Notwithstanding, it correlates with other studies that have found higher knowledge about STIs, HIV, or AIDS transmission and high-risk sexual behavior with little or no precautionary measures against these diseases. This finding also signals great challenge toward the zero AIDS deaths and zero new HIV infections agenda across developing countries [2], [11], [40].

\section{Limitations}

Although the use of only 1-year dataset yielded sufficient information for this study, it, however, prevents the overview of the trends in sexual behavior among the subject overtime. Furthermore, the use of a 2012 dataset could be seen as a limitation considering the dynamism in human lifestyle and behavior.

\section{Conclusion and Recommendations}

The study provided empirical findings on the context of sexual relationship in non-marital or noncohabiting relationship and substance use among the youth in Nigeria. The study found significant positive association between religious practice, educational status, alcohol, and age at first sex as significant contributors to non-marital/non-cohabiting sexual relationship among youths in Nigeria. The study concludes that continued exposure of school-going adolescents to drug or alcohol may pose serious challenge to risky sexual behavior and serious threat to initiatives on zero new HIV infections or zero new AIDS death in Nigeria. It also envisages religion affiliations and religious activities as vital factors in the analysis of substance use and sexual behavior among the youth. Finally, considering the age and proportion of the youth in Nigeria, adequate guidance and policies could discourage substance and alcohol use among the youth in schools. It is also necessary to provide curriculum guidance against the likely widespread of STIs due to their involvement in multiple sexual partnership and non-marital sexual relationship.

\section{References}

1. Federal Republic of Nigeria. National HIV and AIDS Strategic Framework 2017-2021. Federal Republic of Nigeria; 2017.

2. World Health Organization. Global HIVIAIDS Response: Epidemic Update and Health Sector Progress towards Universal Access: Progress Report 2011. Global HIVIAIDS Response: Epidemic Update and Health Sector Progress towards universal Access: Progress Report. Geneva: World Health Organization; 2011. https://doi.org/10.1787/9789264250901-ko

3. McMaster J, Keshav C. Perceptions of normal alcohol use held by Zimbabwean high school students. Cent Afr J Med. 1994;40(4):88-94.

PMid:7954716

4. Morojele NK, Brook JS, Kachieng'a MA. Perceptions of sexual risk behaviours and substance abuse among adolescents in South Africa: A qualitative investigation. AIDS Care. 2006;18(3):215-9. https://doi.org/10.1080/09540120500456243 PMid:16546781

5. Adelekan ML. Self-reported drug use among secondary school students in the Nigerian State of Ogun. Bull Narc. 1989;41(1):109-16

PMid:2765717

6. Adelekan ML, Ndom RJ. Trends in prevalence and pattern of substance use among secondary school pupils in Ilorin, Nigeria. West Afr J Med. 1997;16(3):157-64.

PMid:9329284

7. Pela OA. Patterns of adolescent psychoactive substance use and abuse in Benin City, Nigeria. Adolescence. 1989;24(95):569. PMid:2801280

8. Amoo EO, Igbinoba A, Imhonopi D, Banjo OO, Ajaero CK, Akinyemi JO, et al. Trends, determinants and health risks of adolescent fatherhood in sub-Saharan Africa. Ethiop $\mathrm{J}$ Health Sci. 2018;28(4):433-42.

PMid:30607056

9. Amoo EO, Igbinoba AO, Imhonopi D, Banjo O, Ajaero CK, Akinyemi JO, et al. Trends, Drivers and Health Risks of Adolescent Fatherhood in Sub-Saharan Africa. Proceedings of SOCIOINT $20174^{\text {th }}$ International Conference on Education, Social Sciences and Humanities, 10-12 July 2017- Dubai, 
UAE, (Paper, No. 405); 2017. p. 1257-67.

10. UNAIDS U. Countdown to ZERO: Global Plan Towards the Elimination of New HIV Infections among Children by 2015 and Keeping their Mother Alive. UNAIDS; 2011. https://doi. org/10.1037/e628452012-271

11. UNICEF and UNICEF. Countdown to Zero. Elimination of New HIV Infections among Children by 2015 and Keeping their Mothers Alive. UNICEF; 2012.

12. Adekeye OA, Amoo EO, Adeusi SO, Chenube OO, Ahmadu F, Idoko J. Dataset on perception of public college students on underage drinking in Nigeria. Data Brief. 2019;24:103930. https://doi.org/10.1016/j.dib.2019.103930

13. Edwards JM, Iritani BJ, Hallfors DD. Prevalence and correlates of exchanging sex for drugs or money among adolescents in the United States. Sex Transm Infect. 2006;82(5):354-8. https://doi. org/10.1136/sti.2006.020693

PMid: 16901917

14. Kliewer W, Murrelle L. Risk and protective factors for adolescent substance use: findings from a study in selected Central American countries. J Adolesc Health. 2007;40(5):448-55. https://doi.org/10.1016/j.jadohealth.2006.11.148 PMid: 17448403

15. Lee LK, Chen PC, Lee KK, Kaur J. Premarital sexual intercourse among adolescents in Malaysia: A cross-sectional Malaysian school survey. Singapore Med J. 2006;47(6):476.

16. Adekeye OA, Odukoya JA, Chenube O, Igbokwe DO, Igbinoba $\mathrm{AO}$, Olowookere El. Subjective experiences and meaning associated with drug use and addiction in Nigeria: A mixed method approach. Glob J Health Sci. 2017;9(8):57-65. https://doi.org/10.5539/gjhs.v9n8p57

17. Nigeria UN. UNICEF Nigeria: Programme Document 20142017. Abuja, Nigeria: UNICEF Nigeria; 2013.

18. Rudatsikira, E, Maposa D, Mukandavire Z, Muula AS, Siziya S. Prevalence and predictors of illicit drug use among school-going adolescents in Harare, Zimbabwe. Ann Afr Med. 2009;8(4):21520. https://doi.org/10.4103/1596-3519.59574

19. Adekeye OA, Adeusi SO, Chenube O, Ahmadu FO, Sholarin MA. Assessment of alcohol and substance use among undergraduates in selected private universities in Southwest Nigeria. IOSR J Hum Soc Sci. 2015;20(3):1-7.

20. Olawole-Isaac A, Ogundipe O, Amoo EO, Adeloye D. Substance use among adolescents in sub-Saharan Africa: A systematic review and meta-analysis. S Afr J Child Health. 2018;1:79-84. https://doi.org/10.7196/sajch.2018.v12i2b.1524

21. Odimegwu CO, Amoo EO, De Wet N. Teenage pregnancy in South Africa: Where are the young men involved? S Afr J Child Health. 2018;12:s44-50. https://doi.org/10.7196/sajch.2018. v12i2b. 1523

22. OyewoleBK,Animasahun VJ, Chapman HJ. Tobaccouse in Nigerian youth: A systematic review. PLoS One. 2018;13(5):e0196362. https://doi.org/10.1371/journal.pone.0196362 PMid:29723203

23. Obiechina GO, Isiguzo BC. Curbing the menace of drug use among secondary school students in Nigeria. Eur J Res Reflect Educ Sci. 2016;4(1):53-64.

24. Carroll CR. Drug abuse in Nigeria facts, causes and remedies. In: A Paper Presented at the National Seminar on Drug Abuse Enforcement, Lagos; 1989.

25. Essien CF. Drug use and abuse among students in tertiary institutions-the case of federal university of technology, Minna. $J$ Res Natl Dev. 2010;8(1):35-42.

26. Odejide AO, Ohaeri JU, Ikuesan BA. Alcohol use among
Nigerian youths: The need for drug education and alcohol policy. Drug Alcohol Depend. 1989;23(3):231-5. https://doi.org/10.1016/0376-8716(89)90086-0

PMid:2666075

27. Amoo EO. Emerging teen fatherhood and its implications for national development. J Popul Assoc Niger. 2012;4(1):93-111.

28. Zarrett N, Eccles J. The passage to adulthood: Challenges of late adolescence. New Dir Youth Dev. 2006;2006(111):13-28. https://doi.org/10.1002/yd.179

29. Bearinger LH, Sieving RE, Ferguson J, Sharma V. Global perspectives on the sexual and reproductive health of adolescents: Patterns, prevention, and potential. Lancet. 2007;369(9568):122031. https://doi.org/10.1016/s0140-6736(07)60367-5

30. Gupta N, Mahy M. Sexual initiation among adolescent girls and boys: Trends and differentials in sub-Saharan Africa. Arch Sex Behav. 2003;32(1):41-53.

PMid:12597271

31. Hindin MJ, Fatusi AO. Adolescent sexual and reproductive health in developing countries: An overview of trends and interventions. Int Perspect Sex Reprod Health. 2009;35(2):5862. https://doi.org/10.1363/3505809

PMid:19620089

32. Slap GB, Lot L, Huang B, Daniyam CA, Zink TM, Succop PA Sexual behaviour of adolescents in Nigeria: Cross sectional survey of secondary school students. BMJ. 2003;326(7379):15. https://doi.org/10.1136/bmj.326.7379.15

PMid:12511453

33. Federal Ministry of Health. National HIV and AIDS and Reproductive Health Survey, 2012 (NARHS Plus). Federal Ministry of Health, Federal Republic of Nigeria; 2013. p. 527. Available from: https://www.naca.gov.ng/wp-content/ uploads/2016/11/NARHS-Plus-2012-Final-18112013.pdf.

34. Eaton DK, Kann L, Kinchen S, Shanklin S, Ross J, Hawkins J, et al. Youth risk behavior surveillance-United States, 2009. MMWR Surveill Summ. 2010;59(5):1-42. https://doi. org/10.1037/e307132005-001 PMid:20520591

35. Hall PA, Holmqvist M, Sherry SB. Risky adolescent sexual behavior: A psychological perspective for primary care clinicians. Top Adv Pract Nurs J. 2004;1.

36. Macro I; National Population Commission. Nigeria Demographic and Health Survey 2013. National Population Commission; 2014.

37. Odukoya JA, Adekeye O, Igbinoba AO, Afolabi A. Item analysis of university-wide multiple choice objective examinations: The experience of a Nigerian private university. Qual Quant. 2018;52(3):983-97. https://doi.org/10.1007/s11135-017-0499-2

38. Fletcher JM, Wolfe BL. The effects of teenage fatherhood on young adult outcomes. Econ Inq. 2012;50(1):182-201. https:// doi.org/10.1111/j.1465-7295.2011.00372.x

39. Murray CE, King K, Crowe A. Understanding and addressing teen dating violence: Implications for family counselors. Fam J. 2016;24(1):52-9. https://doi.org/10.1177/1066480715615668

40. Joint United Nations Programme on HIVIAIDS (UNAIDS). An ambitious treatment target to help end the AIDS epidemic. Joint United Nations Programme on HIVIAIDS (UNAIDS); 2014. Available from: http://www.unaids.org/sites/default/files/ media_asset/90-90-90_en.pdf. 